\title{
Russian-language Imprints from Switzerland: A Digital Collection on e-rara.ch
}

Eva Maurer

(eva.maurer@ub.unibe.ch)

Universitätsbibliothek Bern, Schweizerische Osteuropabibliothek, Bern /

Switzerland

Postprint. To cite this article: Eva Maurer (2021): Russian-language Imprints from Switzerland: A Digital Collection on e-rara.ch, Slavic \& East European Information Resources, DOI:10.1080/15228886.2021.1878592

\section{ABSTRACT}

Switzerland was one of the hotspots of the Russian political emigration in the years immediately before the revolution of 1905 , with Geneva being one of the main centers of Russian émigré printing in the first years of the $20^{\text {th }}$ century. Many of these imprints are now accessible in a digital collection on the Swiss platform erara.ch. These works originate from several special collections of the

Schweizerische Osteuropabibliothek (Swiss Library of Eastern Europe) in Bern. Of special interest is the 'Davos Russian library', a Russian-language library from the beginning of the $20^{\text {th }}$ century whose holdings offer insights into the reading interests and activities of Russians in Switzerland before the October Revolution.

\section{KEYWORDS}

Digital collections; Russian publishing abroad; Russian exile; Switzerland Russian revolution; Russian printing culture; Davos Russian library

Switzerland is well known for having four national languages, but Russian is not one of them. Yet between the late 1880s and 1920, approximatively 600 to 800 works in Russian were printed in Switzerland, mostly books and bro- chures, but also periodicals and newspapers - a legacy of the around 8,000 Russian emigrants living, working, and writing in Switzerland in the years before the Russian Revolution. ${ }^{1}$ A digital collection on the Swiss digitization platform e-rara.ch makes over 300 of these works accessible worldwide through a collection called "Russian exile publications." 2 These works come from the special collections of the Swiss Library of Eastern Europe (Schweizerische Osteuropabibliothek), Switzerland's largest library focusing on Eastern Europe. Both the individual titles and the original collections in which they were preserved give interesting insights into Russian life in Switzerland in the years leading up to 1917. After a brief introduction into the history of Russian publishing in Switzerland before the Revolution, I will give an overview of the history and holdings of the most important library collection, the "Davos Russian library." I will also describe a few other interesting types of documents that can be found on e-rara.ch. 
After the Europe-wide national and liberal protests and upheavals of 1848, Switzerland became an attractive place of exile for many political emigrants from different European countries. ${ }^{3}$ Its liberal government at the time mostly tolerated the political activity of the exile communities. Russian-language publishing in Switzerland started in the 1860s when three major Russian political, each representing a different branch of political thinking, installed themselves in Switzerland. Alexander Herzen (Gertsen) transferred the opposition periodical Kolokol from London to Geneva in 1865. Mikhail Bakunin, the "father of Russian anarchism", likewise spent his last years, from 1863 to 1876, in Switzerland; while Petr Lavrov, an eminent voice in early narodnichestvo, published "Vpered!" in Zürich/Winterthur from 1873 to 1874 (see Figure 1).

In the 1880s, Russian-language publishing in Switzerland expanded significantly. A few specialized printers, all emigrants from the Russian empire, began to set up printing houses and shops, the most important among them being Mikhail El'pidin in Geneva, who not only ran a publishing house but also a bookstore and library which were important meeting places for the Russian community. ${ }^{5}$ At the same time, the Russian-language community in Switzerland continued to grow. Political oppression and the exclusion of women from university studies led many students from the Russian empire, a large number of them being women, to flock to Swiss universities where they soon formed a sizable group, especially at the medical faculties. If before, a few "Slavic" presses printed mostly general material in Slavic languages, issuing polemical literature now became one of the core activities of the newly formed political movements and parties, which stemmed from this younger genera- tion of emigrants and politically active students and who favored a more radical approach to political change in the Russian empire.

The most important producers of Russian-language publications in the $1880 \mathrm{~s}$ and $1890 \mathrm{~s}$ were the different groups within the socialist spectrum, starting with Georgii Plekhanov's and Pavel Aksel'rod's Grupa osvobozhdeniia truda" (1883), which in turn would be one of the founding groups of the Russian Social-Democrat Workers' Party (Rossiiskaia sotsial'-demokraticheskaia rabochaia partiia, RSDRP). ${ }^{6}$ At the same time, the czarist regime intensified its attempt to control these émigré groups after one of the most radical and violent groups, the Narodnaia volia (founded in 1879 after a split from the narodniki movement) had assassinated Czar Alexander II in 1881. The czarist regime tried, with limited success, to increase political pressure on Switzerland's authorities to tighten the grip on Russian publishing in Switzerland. At the same time Imperial Okhrana agents also searched (illegally) and partially destroyed Narodnaia volia's printing press several times. 


\section{VORWAETS!}

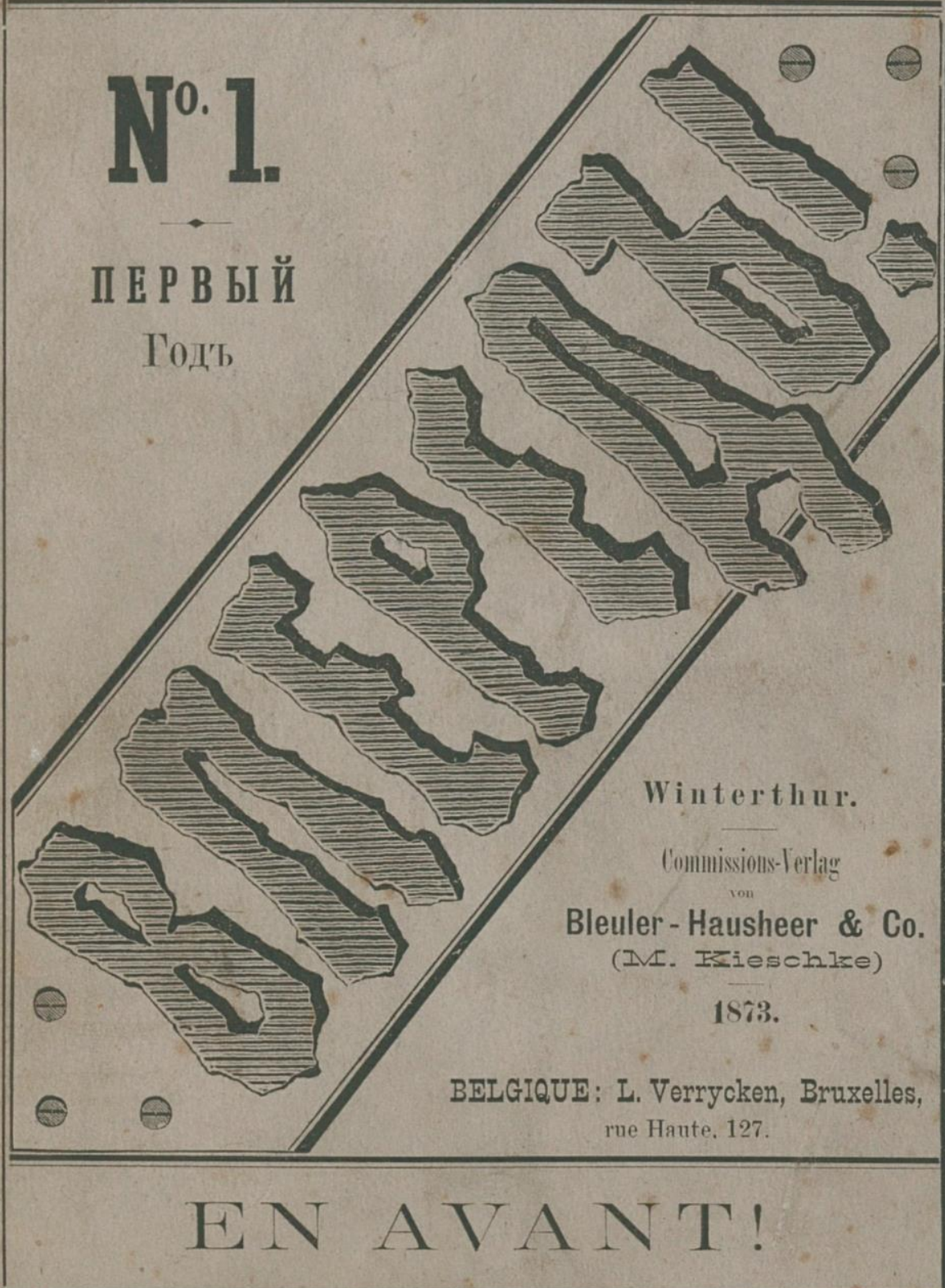

Figure 1. Vpered, Zürich $1873 .^{4}$ 
Geneva was the hub of Russian-language printing from the beginning, and its importance grew steadily toward the end of the nineteenth century. After the establishment of the RSDRP in 1898, the production of political literature in Russian dramatically increased. About seventy to eighty percent of all Swiss Russian imprints between 1860 and 1905 were produced in the five years between 1900 and 1905. In this short period, Geneva's place among Russian printing centers in exile was more important than London or Paris. Younger socialists like Vladimir Lenin or Lev Trotsky came to live in Switzerland, joining the older generation like Plekhanov, Akselrod, or Vera Zasulich. From 1904 to 1905, the RSDRP's most important organ, the newspaper Iskra (led by Lenin, Plekhanov and Yuliy (Lev) Martov), had its head office in Geneva. Ironically, it was located on the same street where the opposing Social revolutionaries published their main paper, Revoliutsionnaia Rossiia: the rue de Carouge indeed boasted such a dense offer of Russian exile activities that the locals nicknamed it karuzhka, Russianizing the street's name. ${ }^{8}$

This political literature published abroad served more than one purpose. The periodicals and the theoretical debates that took place within their pages were directed at the émigré communities themselves, thus creating a multivocal space for discussion, reflection, arguments, and polemics in the process of which new streams and directions, groups, and parties were formed. However, much of the literature was also published for a broader public and was meant to be distributed back in Russia, where it was clandestinely smuggled in many forms. Publishers printed short brochures on important topics of the day like the Russo-Japanese war (1904-1905), political trials and prisoners, land reform etc., on a few sheets of thin paper so that they could be transported inconspicuously. All of it was, of course, only printed abroad because it could not be printed within the Russian empire itself. So in 1905 , when restrictions on domestic printing were lifted, many revolutionaries traveled back to Russia itself and helped set up local printing presses, which proliferated all over Russia. Consequently, Russian-language printing in Switzerland experienced a sharp decline after 1905, and it would never again reach its former all-time high. ${ }^{9}$

\section{The "Davos Russian Library": A Collection and Its History}

Geneva, Zürich, Lausanne and Bern, with their universities and cultural life, were the obvious hot spots of the Russian colony in Switzerland. However, another less-known center of the Russian emigration in Switzerland deserves mention here: Davos, an alpine resort village (kurort in German and Russian) in the Swiss mountain canton of Graubünden. It was widely known for its success in treating tuberculosis and had acquired a steady clientele of Russian patients in the years leading up to World War I, including some already living 
in Europe, but others also coming as tourists or patients directly from the Russia. In those years, guests from the Russian empire made up the secondlargest group of foreigners in Davos. Though they mingled with others in the numerous sanatoria and public venues in the town, they also had their own institutions. A Russian society for mutual aid was set up there in 1902, and in 1909, a "Russian people's sanatorium" (russkaia narodnaia sanatoriia) was installed to offer less well-to-do Russians the possibility for tuberculosis treat- ment. Wealthy Russian guests financed it mostly by donations and generous subsidies - its history and its account books from 1913 give insight into the daily life of Russian patients in Davos (see Figure 2).$^{10}$ In 1911, the Russian empire even established a vice-consulate in Davos. Its presence there, however, was short-lived. ${ }^{11}$

Since tuberculosis patients usually had a lot of time on their hands, a Russian library was established already by 1899 . Over the next fifteen years, it grew steadily to become the "Davos Russian library" (officially, the "Biblioteka Russkogo Obshchestva im. Tolstogo - Bibliothèque Russe de Davos"), a collection of almost 3,000 titles. After World War I and the Russian Revolution, however, only a small Russian colony of people still in need of treatment and with few resources remained in Davos. A few books from the 1920s and 1930s in the collection suggest that the library was still in use, but over time, activities ceased altogether. Luckily, the library was preserved more or less entirely and must have been kept in a favorable environment, until in 1963 the community council of Davos decided to donate it to the Osteuropa-Bibliothek in Bern. Library staff in Bern subsequently cataloged the holdings (on a rather basic level) and preserved them as a separate collec- tion with special call numbers.

Of the over 2,900 titles in the "Davos Russian library", more than ninety percent were published prior to 1915 , and almost all of them are in Russian (a few French and German nonfiction titles, some on tuberculosis treatments, being the exception).$^{13}$ An overview over the collection as of 1912 can be found in their printed catalog available in digitized form (see Figure 3). ${ }^{14}$

The catalog is one of a dozen titles printed in Davos itself during these years; others include a Russian guidebook to Davos from 1911 (see Figure $4)^{16}$ and the literary almanac Za rubezhom (1909-1910) to which the prominent Mensheviks Fedor Dan and Lev (Yulii) Martov contributed columns (see Figure 5). ${ }^{17}$

The bulk of the holdings of the "Davos Russian library" begins in the 1870s. These older works (and newer ones as well) were probably donated in smaller bundles or as individual works from patrons or from people working for the library. Often, they bear stamps and selling marks from Russian libraries, political reading circles, and booksellers all over Europe, providing glimpses of their journeys and previous readers. As an example, StepniakKravchinskii's 


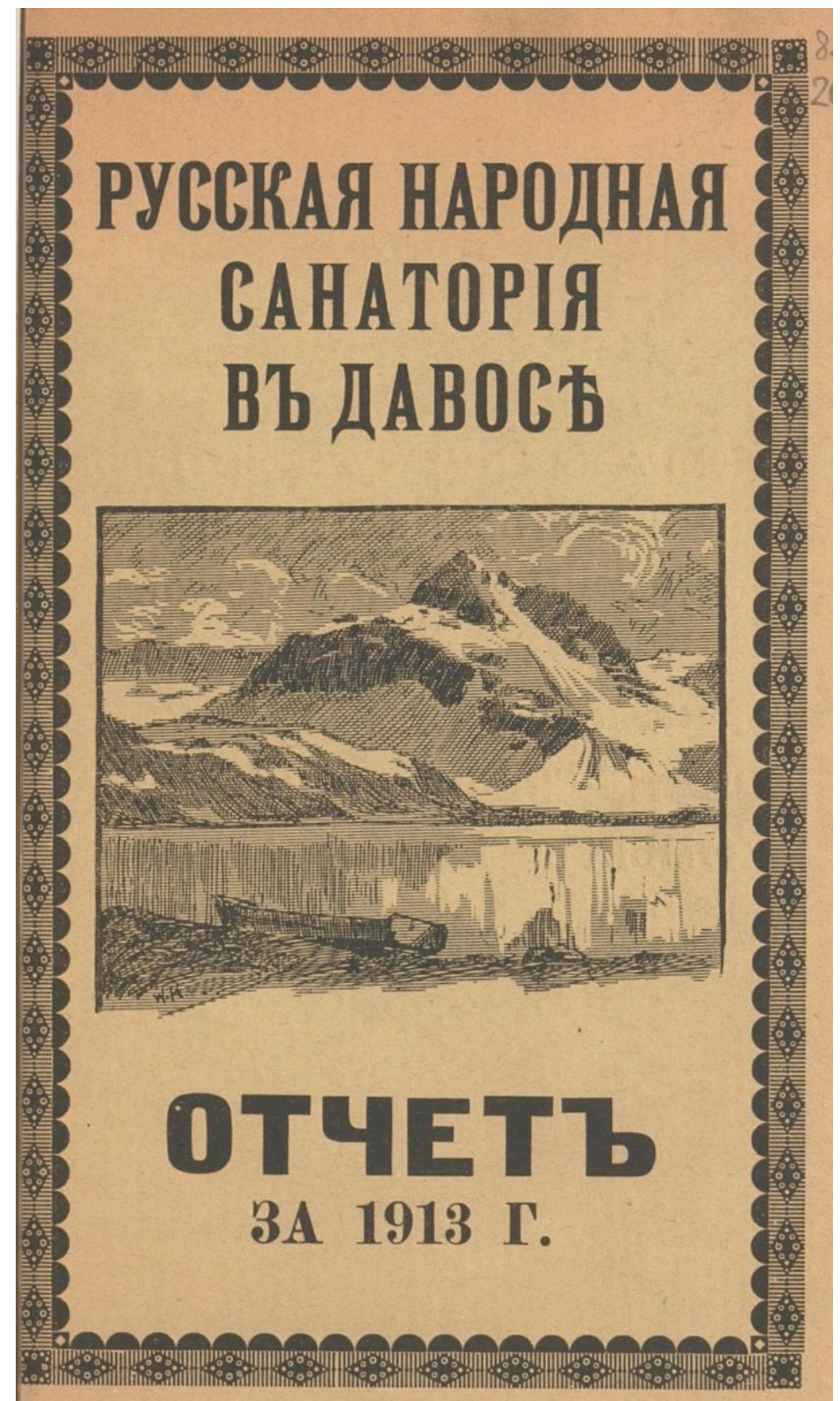

Figure 2. Russkaia narodnaia sanatoria, Davos $1914 .^{12}$

Andrei Kozhukhov (1898) bears the stamp of the "Russkoe obshchestvo v Davose," but once belonged to the "Librarie russe de Genève", and carries the stamp of the library and archive of the RSDRP in Geneva (see Figure 6). 


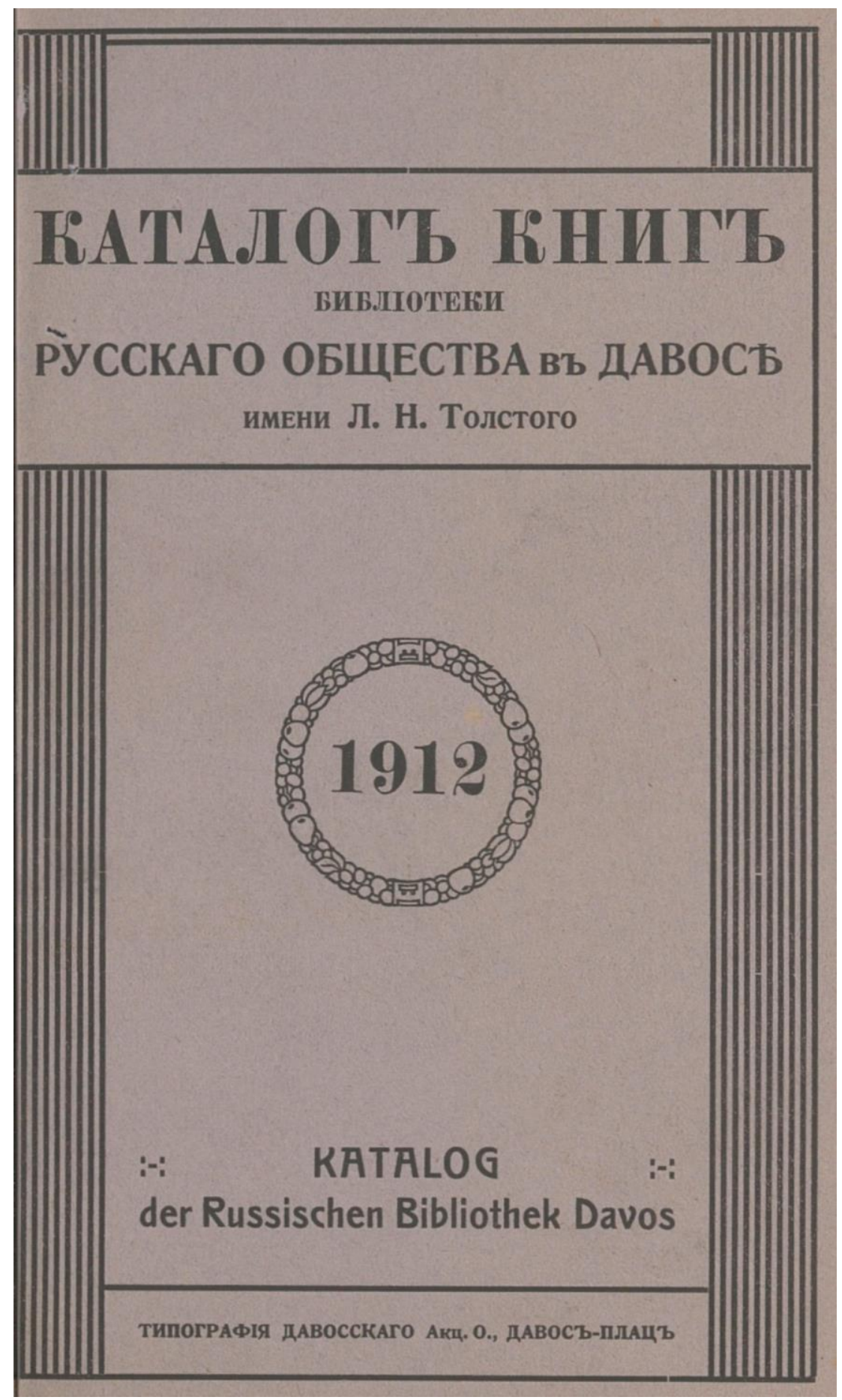

Figure 3. Catalog of the "Davos Russian library", Davos $1912 .{ }^{15}$

The Davos Russian library's holdings encompass the wide reading interests of an educated Russian public such as one could expect in a rather fashionable 


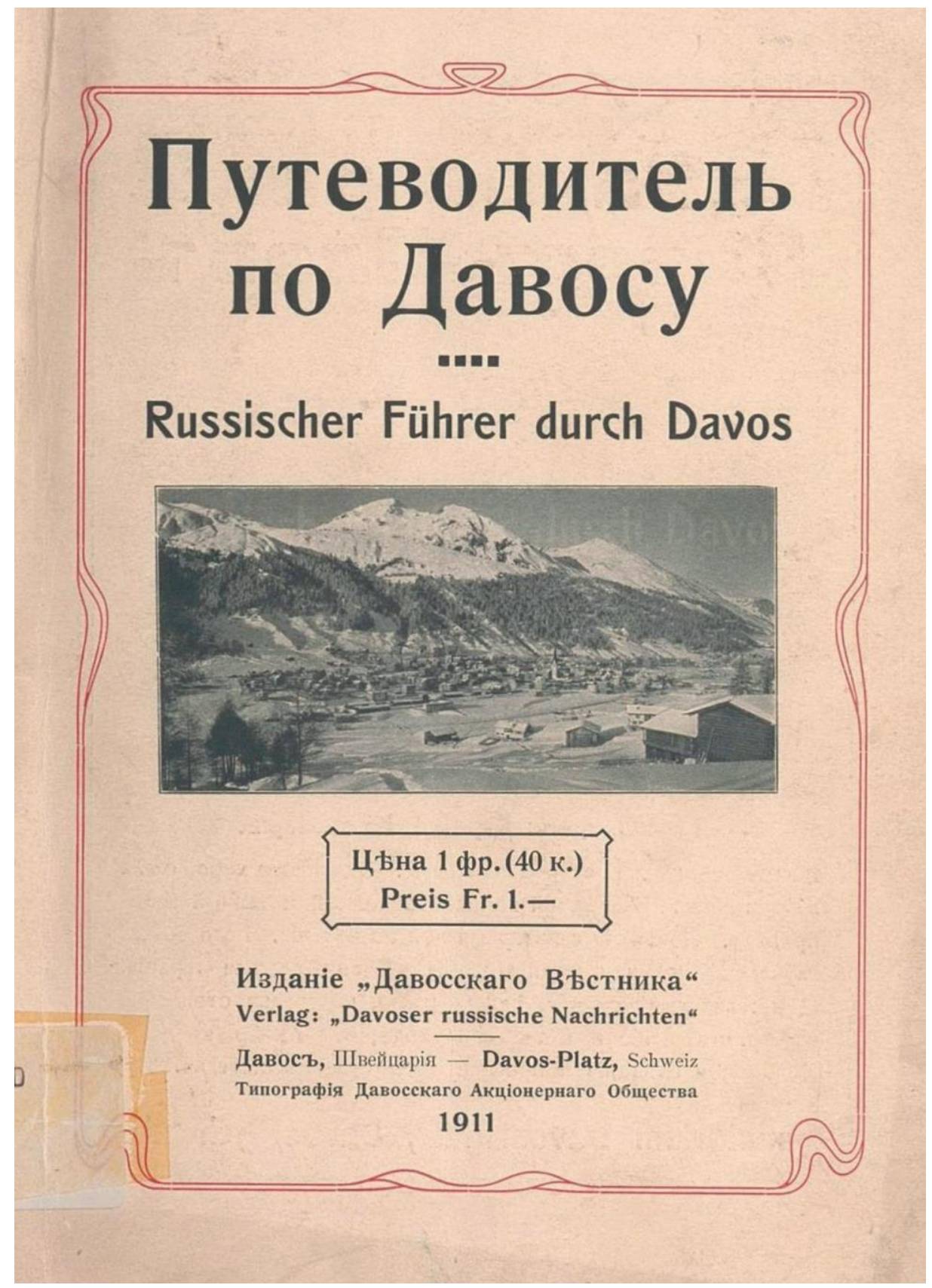

Figure 4. Guidebook to Davos/Putevoditel' po Davosu/Russischer Führer durch Davos, Davos 1911. ${ }^{18}$

mountain resort. They include Russian literary classics and more contemporary Russian literature, some of which could only have been published abroad (such as some works of Tolstoy, for example), translations of foreign popular fiction (from Jack London to Arthur Conan Doyle), literary almanacs and the 


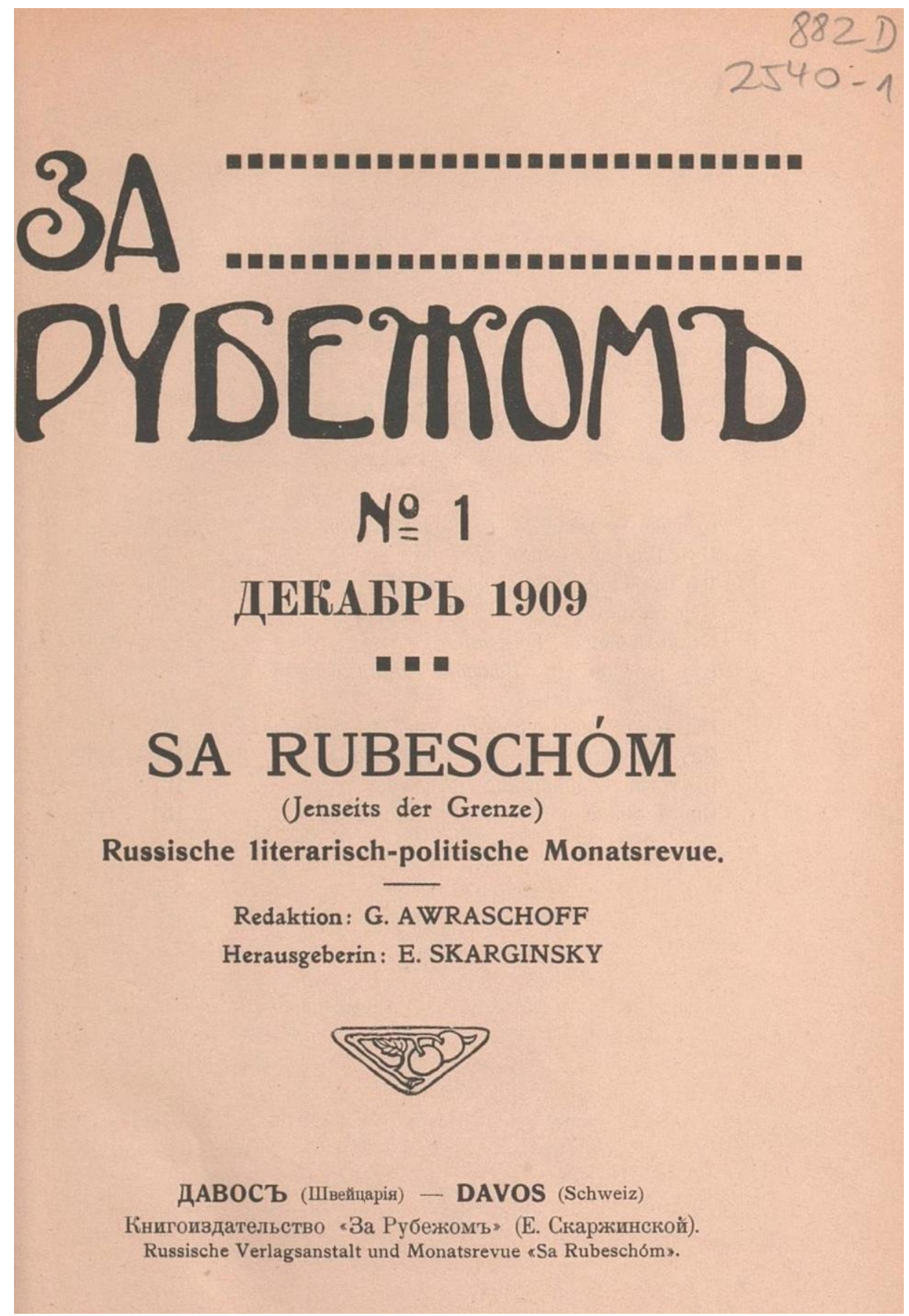

Figure 5. Za rubezhom, Davos 1909-1910. ${ }^{19}$

"thick journals" (tolstie zhurnaly) that were a staple of Russian literary publish- ing. Quite a number of contemporary women writers were among the authors, both foreign and Russian, and mostly popular-fiction authors. A large portion 


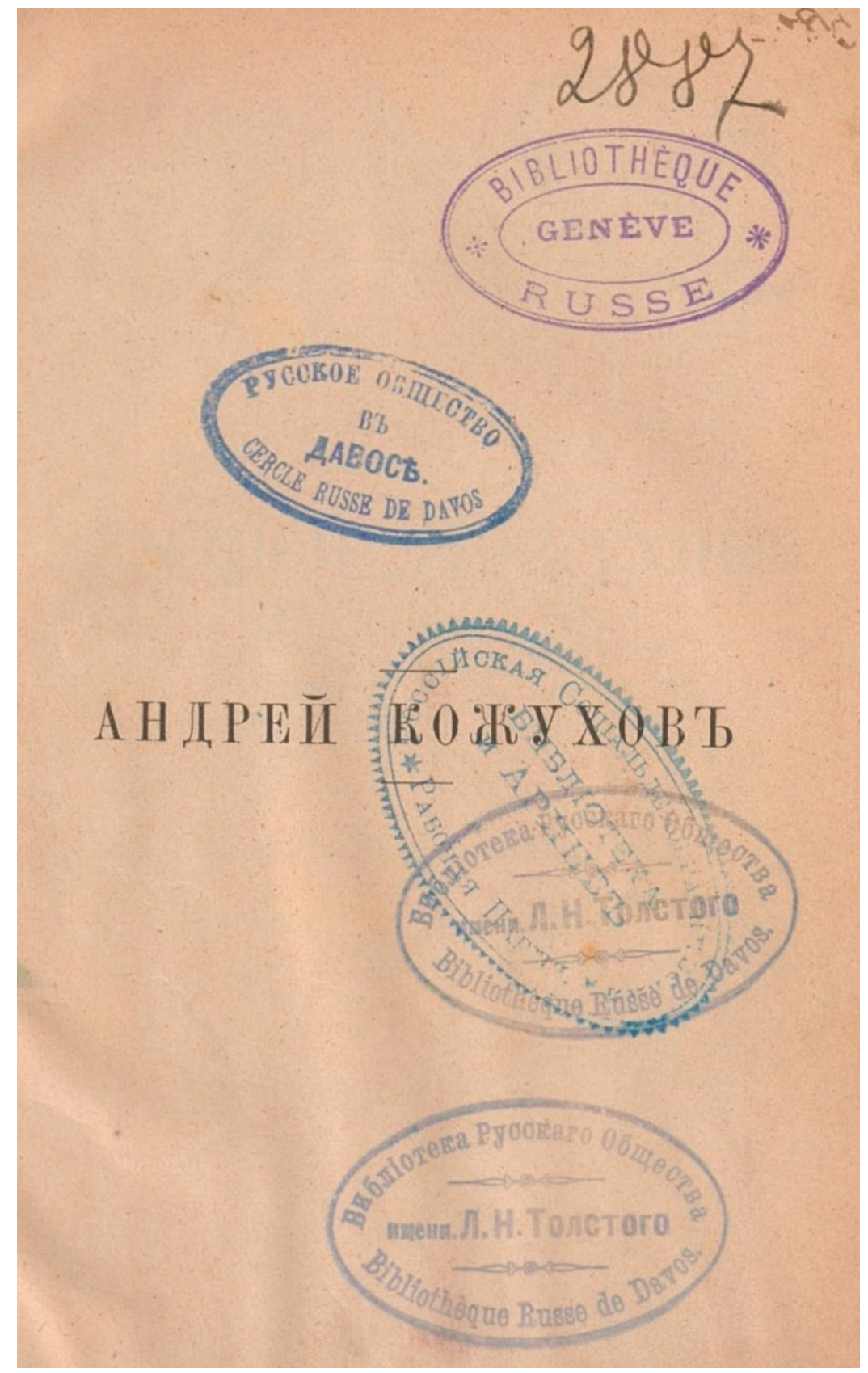

Figure 6. Stepan Kravchinskii, Andrei Kozhukhov, Geneva 1898. ${ }^{20}$

of the library collection is comprised of nonfiction, especially political literature, often published outside Russia.

In choosing a first selection to digitize, the staff at the Schweizerische Osteuropabibliothek have mainly focused on such political works in a first phase. Not only are they a part of Swiss printing heritage often overlooked, but 
they are also often only poorly preserved. Their ephemeral nature shows in the cheap printing and thin paper and in their small size (often just 8-24 pages). These were texts made to be circulated and read by more than one person but also to be hidden easily at any moment - all of which is not conducive to their preservation over more than a hundred years. For library purposes, stacks of them were bound together in one volume. This makes digitization more difficult because of tight bindings, missing covers, and cut pages; however, it certainly helped to preserve them over time.

\section{Further Resources: The Leysin Collection, Newspapers and Periodicals and Works from the (Post-) Revolutionary Years}

Apart from the Davos collection, digitized texts in the e-rara collection "Russian exile publications, also come from the village's counterpart in French-speaking Switzerland: Leysin, a small mountain village not far from Lausanne, similarly became an important spot for tuberculosis treatment in the early twentieth century, albeit much smaller. Just as in Davos, a Russian mutual aid society (Société russe de bienfaisance de et à Leysin) was active in the 1910s and up to the mid-1920s, and it had its own library as well. Parts of this library, disbanded and split up probably after World War II, have come to the Schweizerische Osteuropabibliothek by way of a private donation. These approximately 300 titles include mostly political literature by different political groups, including Social Revolutionaries, Social Democrats, the Jewish Bund and other groups. Again, many thin brochures were bound together in volumes,--often across party lines,-including both full publications and excerpts or special prints such as one with a stamp of the Zürich section of the Polish socialist party (PPS) ${ }^{21}$ Most of these titles date between 1900 and 1905.

Another smaller, but interesting category of materials in the digitized collection on e-rara.ch are Russian-language periodicals and newspapers, from the same time period, which were published outside Russia. There are rare Swiss Russian-language publications, such as the anarchist newspaper Rabochee znamia, published in Lausanne from 1915 to 1917, or the Otkliki, edited by Petr Zvezdich (Petr Rotenshtern, 1868-1944) in Bern in 1919, to our knowledge the only Russian newspaper ever published in the Swiss capital (see Figure 7).

They belong to a larger group of ephemeral imprints-leaflets, newspapers and periodicals-which were fragile and in urgent need of preservation when the Schweizerische Osteuropabibliothek first acquired them. We have therefore also digitized a few Russian emigrant newspapers published in other European cities alongside ephemeral political pamphlets and periodicals from a wider socialist and anarchist specter, including items in Esperanto ${ }^{23}$ or Yiddish. ${ }^{24}$ 


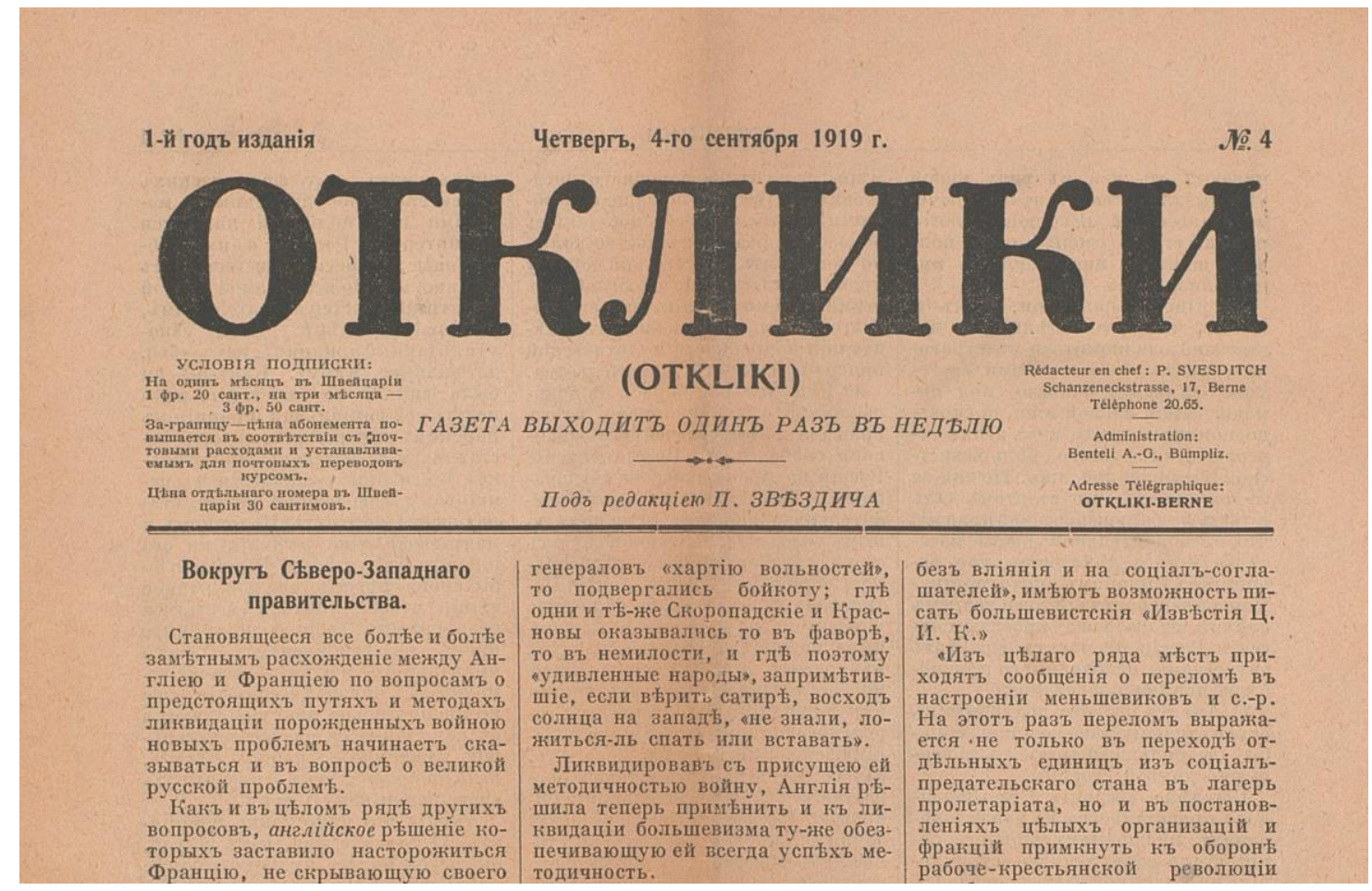

Figure 7. Otkliki, Bern 1919. ${ }^{22}$ 

A third group represents works published in Switzerland during the years of Revolution and Civil War which reflect, discuss, and argue about the ongoing changes in Soviet Russia. While the authors were still Russian emigrants, after 1917 they often wrote or published their work in French or German, intending to reach not just the (dwindling) émigré community, but a wider audience in Switzerland and internationally. While initially many authors were enthusias- tic about the end of the czarist order, most of these writers the ones who stayed after 1917 - were disillusioned after the first year of Bolshevik rule. A good example is Boris (Baruch) Chlenov's La Russie de demain, published in the publishing house "Alexander Herzen" in Lausanne (which had also pre- viously published works in Russian). Chlenov, a doctor who had previously written a very popular Russian-language travel guide to Switzerland, ${ }^{25}$ passio- nately argued for a future Russia in the form of a federal democratic republic with wide autonomy for the regions, yet still recognizing "the general culture" and holding in a high esteem "the Russian language and the Russian genius (le génie russe)". ${ }^{26}$

Using the Collection on e-rara.ch: A Few Tips on Searching and Finding Materials

E-rara.ch, the platform hosting this collection, is a Swiss cooperative project hosting digital collections from various Swiss university, cantonal, and other research libraries. ${ }^{27}$ Its initial and main focus is on making Swiss imprints from the sixteenth to the early twentieth century available in digital form. However, the platform also hosts different special collections from its partner institutions. A visual redesign in 2020 made the platform more user-friendly and attractive and implemented IIIF compatibility. The interface is available in English, French, German, and Italian. All material is available in the public domain. Users can download full titles as PDFs or individual pages as JPGs in different resolutions, thus allowing the reuse of the images in a variety of contexts.

Simple and advanced text search are available, with a variety of filter options , including filtering by media type, place of publication, date or date range of publishing etc. Users should be aware that the catalog metadata is available in transliterated form only, using the DIN/ISO transliteration system for Slavic languages, as it is widely used in German-speaking areas: thus, when searching across the metadata, users need to apply this transliteration system. Places of publication are transliterated from their appearance on the cover and not normalized, meaning you sometimes have to search or filter for "Lozanna", not Lausanne, or "Zeneva", not "Genève" (diacritic marks can be omitted for searching purposes). Full text search has been enabled wherever possible and functions reasonably well even with the many works still written in pre- revolutionary Russian orthography. Thus, users can do a full text search of 
one work, a selection, or all digital items using the Advanced Search fields, and this has to be done in Cyrillic script. Searches are truncated automatically.

Plans for the future include further digitization, especially for works published in the years immediately after the revolution, as far as copyright allows. We also hope improve partially rudimentary metadata, such as resolving more pseudonyms, tracking down and adding additional publishing information, and, if possible, adding vernacular titles and author names in order to increase worldwide visibility and ease of searching. In the meantime, all historical works in our collections are available for digitization on demand. ${ }^{28}$ For any suggestions about further digitization and for additional input, please contact the author.

\section{Notes}

1 Exact numbers are difficult to ascertain since many brochures appeared without a publisher's notice on the cover or with fake information. The number is based on the holdings of the Swiss National Library, which holds probably the most complete collection of Russian prints in Switzerland. See also Eugénie Lange, "Schweizer Drucke in russischer Sprache," in Fünfzig Jahre Schweizerische Landesbibliothek : 1895-1945 = La Bibliothèque nationale suisse : un demi siècle d'activité ([Bern]: [Schweizerische Nationalbibliothek], 1945), 68-76, https://www.ehelvetica.nb.admin.ch/directAccess? callnumber=nbdig-724171.

$2 \mathrm{https} / / / \mathrm{www} . e-$ rara.ch/nav/classification/13070746

3 The literature on Russian and other East European emigrants in Switzerland is vast and I can just name a few starting points, for example the collection Monika Bankowski, ed., Asyl und Aufenthalt : die Schweiz als Zuflucht und Wirkungsstätte von Slaven im 19. und 20. Jahrhundert (Basel: Helbing \& Lichtenhahn, 1994); recently also Julia Richers, "Osteuropäische Revolutionärinnen und Revolutionäre im Schweizer Exil," in Zimmerwald und Kiental: Weltgeschichte auf dem Dorfe, ed. Julia Richers and Bernhard Degen (Zürich: Chronos-Verlag, 2015), 43-60 On the history of Russian publishing and Russian libraries in Switzerland, a short introduction is Eva Maurer, "Vom Schreiben, Setzen und Sammeln. Russische Drucke in der Schweiz in der Zeit der Revolutionen 1860 bis 1920," Marginalien: Zeitschrift für Buchkunst und Bibliophilie, no. 227 (2017): 32-48 and ead., "Russische Drucke und Druckereien in der Schweiz vor und nach 1917," Religion \& Gesellschaft in Ost und West 100 Jahre Russische Revolution, no. 4-5 (2017): 48-50.

4 Digital Image available via e-rara.ch at the following URL: https://doi.org/10.3931/ erara-49737.

5 Alfred Erich Senn, "M. K. Elpidin: Revolutionary Publisher," Russian Review 41, no. 1 (January 1, 1982): 11-23, https://doi.org/10.2307/129562 - this is but one of the many contributions of A. E. Senn to this field.

6 See, for example Vademecum dlia redaktsii "Rabochego Dela" : sbornik materialov / izd. gruppa "Osvobodozhdenie Truda," 1900, https://doi.org/10.3931/e-rara-53302.

7 On this, see Ladislas Mysyrowicz, "Agents secrets tsaristes et révolutionnaires russes à Genève 1879-1903," Schweizerische Zeitschrift für Geschichte 23, no. 1 (1973): 2972.

8 On Geneva's history and importance in Russian printing, see Ladislas Mysyrowicz, "Imprimeries révolutionnaires russes et 'Orientales' à Geneve 1865-1917," in Cinq siècles d'imprimerie genevoise. Actes du Colloque international sur l'histoire de 
l'imprimerie et du livre à Genève 27-30 avril 1978, ed. Jean-Daniel Candaux and Bernard Lescaze (Geneve: Société d'histoire et d'archéologie, 1981), 297-327; See also his article on the Russian students in Geneva: Ladislas Mysyrowicz, "Université et révolution : les étudiants d'Europe Orientale à Genève au temps de Plékhanov et de Lénine," Schweizerische Zeitschrift für Geschichte 25, no. 4 (1975).

9 Kel'ner's work focuses on the narodnichestvo and other parties, but offers interesting insight into the publishing of political material in general: Viktor Efimovich Kel'ner, Ocherki po istorii izdatel'skoi deiatel'nosti narodnicheskikh i demokraticheskikh partii $i$ organizatsii 1895-1917 gg, Kniga v Rossii v XIX - nachale XX veka (SanktPeterburg: Rossiiskaia natsional'naia biblioteka, 2014).

10 See Russkii dom : dlia nedostatochnykh tuberkuleznykh bol'nykh v Davose (Davos: Tipografiia Davosskago Aktsionernago Obshchestva, 1910), https://doi.org/10.3931/ erara-53314; and Russkaia Narodnaia Sanatoriia v Davosě : otchet za 1913 g (DavosPlac: Tipografiia Davosskago Aktsionernago Obshchestva, 1914), https://doi.org/10. 3931/e-rara-53299.

11 On the history of the Russian colony in Davos, see Bischof, Petra, "Russen in Davos: die russische Kolonie von 1900 bis 1918," in Davos : Profil eines Phänomens, ed. Ernst Halter (Zürich: Offizin, 1994), 47-53; and Florian Rohner, "Im 'Tal des Sterbens und der Wiedergeburt' : russische Kur- und Urlaubskultur in Davos zur Zeit der Belle Epoque" (Lizenziatsarbeit, Zürich, Zürich, 2009). A contemporary look on the colony from 1916 is N. A. Kas'ianov, K kharakteristike uslovii obshchestvennoi deiatel'nosti v russkoi kolonii Davosa (Zürich: Orell Füssli, 1916), https://doi.org/10.3931/e-rara53493 .

12 Digital image available via e-rara.ch at the following URL: https://doi.org/10.3931/ erara-53299.

13 Searching in https://ubbern.swisscovery.slsp.ch for the call numbers «SOB 882 D" gives an overview over the collection. The modern call numbers do not represent the original order of the collection as the previous call numbers were only partly preserved on the books. The catalog from 1912 indicates the original structure and call number until that date.

14 See Katalog knig biblioteki russkogo obshchestva v Davose imeni L.N. Tolstogo, http:// doi.org/10.3931/e-rara-53431.

15 Digital image available via e-rara.ch at the following URL: https://doi.org/10.3931/ erara-53431.

16 Putevoditel' po Davosu = : Russischer Führer durch Davos, 1911, https://doi.org/10.3931/ e-rara-53081.

$17 \mathrm{Za}$ rubezhom : ezhemesiachnyi literaturno-nauchnyi $i$ politicheskii zhurnal $=S a$ Rubeschóm (Jenseits der Grenze) : russische literarisch-politische Monatsrevue, 1909, https://doi.org/10.3931/e-rara-53474.

18 Digital image available via e-rara.ch at the following URL: https://doi.org/10.3931/ erara-53081.

19 Digital image available via e-rara.ch at the following URL: https://doi.org/10.3931/ erara-53474.

20 Digital image available via e-rara.ch at the following URL: https://doi.org/10.3931/ erara-53061.

21 Pol'skaia Socialisticheskaia Partiia v poslednem piatiletii [excerpt from Nakanune No. 21, no place or year given], https://doi.org/10.3931/e-rara-49704.

22 Digital image available via e-rara.ch at the following URL: https://doi.org/10.3931/ erara-49541.

23 Politika malliberulo : unutagajo dedicita al la afero de politkaj malliberuloj en rusa regno kun speciala konsidero "la katorgon," 1912, http://www.erara.ch/bes_1/13620961. 
24 V pomoshch': izdanie Federatsii Anarchicheskikh Krasnykh Krestov Evropy i Ameriki = Der Hilf-Ruf, 1910, https://doi.org/10.3931/e-rara-49530.

25 See Shveitsariia : klimaticheskie kurorty, mineral'nyia vody, vodolechebnicy i mesta dlia letniago otdycha / Die klimatische Kurorte und Bäder der Schweiz / sostavil Dr. med. B.A. Chlenov v Berne (Shveitsariia) $=$ von Dr. med Tschlenoff, Moskva: Izdanie Kartseva 1897, https://doi.org/10.3931/e-rara-53492.

26 See La Russie de demain / B. Tchlenof, 1919, https://doi.org/10.3931/e-rara-53309; here p. 22 with An excellent insight into Chlenov's interesting life is Thomas Bürgisser, "Boris Tschlenoff : Kurarzt und 'Zaddik,"” in Käser, Künstler, Kommunisten vierzig russisch- schweizerische Lebensgeschichten aus vier Jahrhunderten, ed. Eva Maeder and Peter Niederhauser (Zürich: Chronos Verlag, 2009), 181-85.

27 See https://www.e-rara.ch/wiki/aboutERara?lang=en.

28 This includes all works printed before 1900. See https://www.unibe.ch/university/ser vices/university_library/services/copies_and_scans/ebooks_on_demand/index_eng. html. Patrons can order full digital or even reprinted copies of books. The digitized version of the book will be added to the e-rara collections after a blocking period.

\section{Disclosure Statement}

No potential conflict of interest was reported by the author.

\section{ORCID}

Eva Maurer http://orcid.org/0000-0002-6612-6955 